\title{
The effects of positive end-expiratory pressure on respiratory system mechanics and hemodynamics in postoperative cardiac surgery patients
}

\footnotetext{
J.O.C. Auler Jr. ${ }^{1}$

M.J.C. Carmona ${ }^{1}$,

C.V. Barbas², P.H.N. Saldiva ${ }^{3}$ and L.M.S. Malbouisson ${ }^{1}$
}

\author{
'U nidade de Tratamento Intensivo Pós O peratório, InCorHC, \\ ${ }^{2}$ Unidade de Terapia Intensiva Respiratória, ICHC, \\ ${ }^{3}$ Departamento de Patologia, \\ Faculdade de Medicina, U niversidade de São Paulo, \\ São Paulo, SP, Brasil
}

\section{Correspondence \\ J.O.C. Auler Jr. \\ Instituto do Coração, HC, FMUSP Av. Dr. Enéas Carvalho Aguiar, 44 05403-000 São Paulo, SP Brasil \\ Fax: + 55-11-282-2354 \\ E-mail: auler@ incor.usp.br}

Research supported by Fundação E.J. Zerbini. Publication supported by FAPESP.

Received October 19, 1998 Accepted September 9, 1999

\section{Abstract}

We prospectively evaluated the effects of positive end-expiratory pressure (PEEP) on the respiratory mechanical properties and hemodynamics of 10 postoperative adult cardiac patients undergoing mechanical ventilation while still anesthetized and paralyzed. The respiratory mechanics was evaluated by the inflation inspiratory occlusion method and hemodynamics by conventional methods. Each patient was randomized to a different level of PEEP $\left(5,10\right.$ and $\left.15 \mathrm{cmH}_{2} \mathrm{O}\right)$, while zero end-expiratory pressure (ZEEP) was established as control. PEEP of 15-min duration was applied at 20-min intervals. The frequency dependence of resistance and the viscoelastic properties and elastance of the respiratory system were evaluated together with hemodynamic and respiratory indexes. We observed a significant decrease in total airway resistance $\left(13.12 \pm 0.79 \mathrm{cmH}_{2} \mathrm{Ol}^{-1} \mathrm{~s}^{-1}\right.$ at ZEEP, $11.94 \pm 0.55 \mathrm{cmH}_{2} \mathrm{O} \mathrm{l}^{-1} \mathrm{~s}^{-1}(\mathrm{P}<0.0197)$ at $5 \mathrm{cmH}_{2} \mathrm{O}$ of PEEP, $11.42 \pm$ $0.71 \mathrm{cmH}_{2} \mathrm{O} \mathrm{l}^{-1} \mathrm{~s}^{-1}(\mathrm{P}<0.0255)$ at $10 \mathrm{cmH}_{2} \mathrm{O}$ of PEEP, and 10.32 \pm 0.57 $\mathrm{cmH}_{2} \mathrm{O} \mathrm{l}^{-1} \mathrm{~s}^{-1}(\mathrm{P}<0.0002)$ at $15 \mathrm{cmH}_{2} \mathrm{O}$ of PEEP $)$. The elastance $\left(\mathrm{E}_{\mathrm{rs}}\right.$; $\left.\mathrm{cmH}_{2} \mathrm{O} / \mathrm{l}\right)$ was not significantly modified by PEEP from zero $(23.49 \pm$ $1.21)$ to $5 \mathrm{cmH}_{2} \mathrm{O}(21.89 \pm 0.70)$. However, a significant decrease $(\mathrm{P}<0.0003)$ at $10 \mathrm{cmH}_{2} \mathrm{O} \mathrm{PEEP}(18.86 \pm 1.13)$, as well as $(\mathrm{P}<0.0001)$ at $15 \mathrm{cmH}_{2} \mathrm{O}(18.41 \pm 0.82)$ was observed after PEEP application. Volume dependence of viscoelastic properties showed a slight but not significant tendency to increase with PEEP. The significant decreases in cardiac index $\left(1 \mathrm{~min}^{-1} \mathrm{~m}^{-2}\right)$ due to PEEP increments $(3.90 \pm 0.22$ at ZEEP, $3.43 \pm 0.17(\mathrm{P}<0.0260)$ at $5 \mathrm{cmH}_{2} \mathrm{O}$ of PEEP, $3.31 \pm 0.22$ $(\mathrm{P}<0.0260)$ at $10 \mathrm{cmH}_{2} \mathrm{O}$ of PEEP, and $3.10 \pm 0.22(\mathrm{P}<0.0113)$ at 15 $\mathrm{cmH}_{2} \mathrm{O}$ of PEEP) were compensated for by an increase in arterial oxygen content owing to shunt fraction reduction (\%) from $22.26 \pm$ 2.28 at ZEEP to $11.66 \pm 1.24$ at PEEP of $15 \mathrm{cmH}_{2} \mathrm{O}(\mathrm{P}<0.0007)$. We conclude that increments in PEEP resulted in a reduction of both airway resistance and respiratory elastance. These results could reflect improvement in respiratory mechanics. However, due to possible hemodynamic instability, PEEP should be carefully applied to postoperative cardiac patients.
Key words

- Postoperative cardiac surgery

- PEEP

- Respiratory mechanics

- Hemodynamics 


\section{Introduction}

Pulmonary dysfunction is a significant cause of postoperative morbidity following open-heart surgery $(1,2)$. The underlying causes seem to be multifactorial, including effects of anesthesia and muscle paralysis, sternotomy, inflammatory reactions due to extracorporeal circulation, increase in extravascular lung water, alveolar collapse and altered chest wall mechanics $(3,4)$. Atelectasis and hypoxemia are the main clinical findings. Atelectasis seems to be caused by reduced lung volume and small airway collapse $(5,6)$. Hypoxemia may reflect increased intrapulmonary shunt due to collapsed lung areas and/or altered ventilation-perfusion ratio (3). To reopen atelectatic lung units and improve arterial oxygenation, different levels of positive end-expiratory pressure (PEEP) have been proposed, most of them based on improvement of the oxygenation index $(7,8)$. To our knowledge, few studies of respiratory mechanical properties are available about postoperative cardiac patients, submitted to PEEP to reopen collapsed lungs (9). Nevertheless, several investigators have shown that PEEP improves arterial oxygenation, although there is controversy regarding the proper level of PEEP to obtain alveolar opening and stabilization, causing minimal hemodynamic instability and barotrauma (10). It is also important to note that postoperative cardiac patients frequently may present severe hypoxemia, due to atelectasis that requires an alveolar recruitment strategy, employing high levels of PEEP. Simple bedside radiography is considered a poor method to detect postoperative atelectasis (6). Therefore, PEEP should be routinely employed in maneuvers for alveolar opening in the presence of hypoxemia. However, even though PEEP is recommended for alveolar reopening, the presence of hemodynamic instability can be further worsened by elevated inspiratory pressures and PEEP. In the present investigation, we studied the effects of dif- ferent levels of PEEP on respiratory system mechanical properties and oxygenation indexes, as well as its influence on the cardiovascular system in postoperative cardiac surgery patients.

\section{Material and Methods}

After approval by the Institutional Ethics Committee, 10 patients ( 7 males) gave informed written consent to participate in this study. Mean age was 52.3 years (37 to 59 ) and mean weight $66.7 \mathrm{~kg}$ (54 to 87). All patients underwent coronary bypass graft and were studied consecutively during the immediate postoperative period while still under the effects of anesthesia. Surgical procedure and anesthesia were standardized (midazolam, fentanyl and pancuronium bromide), and all patients were submitted to cardiopulmonary bypass with a membrane oxygenator. Inclusion criteria were: previously normal ejection fraction, absence of chronic lung disease, bypass time of 90 to $120 \mathrm{~min}$, satisfactory circulation (absence of vasoactive drugs) and adequate gas exchange parameters upon admission to the intensive care unit.

\section{Respiratory mechanical data}

The patients were anesthetized and paralyzed and initially ventilated with a constant flow ventilator (Bear 5, Bear Medical Systems, Riverside, CA, USA) using an $\mathrm{FIO}_{2}$ of 0.6 , tidal volume $\left(\mathrm{V}_{\mathrm{t}}\right)$ of 8 to $10 \mathrm{ml} / \mathrm{kg}$, inspiratory square-wave flow of $1 \mathrm{l} / \mathrm{s}$ and respiratory frequency of 10 cycles $/ \mathrm{min}$. The end inflation occlusion method was used to measure the resistive and elastic properties of the respiratory system (11). Respiratory elastance $\left(E_{\mathrm{rs}}\right)$ was computed by dividing $\mathrm{P}_{\mathrm{el}, \mathrm{rs}}$ by the tidal volume (12). Care was taken to avoid leaks in the system. Airflow (V) changes in lung volume $\left(\mathrm{V}_{1}\right)$ and tracheal pressure $\left(\mathrm{P}_{t r}\right)$ were obtained directly from the ventilator and stored on an IBM personal 
computer (IBM PC, IBM Computers, São Paulo, SP, Brazil) through a 12-bit analog to digital converter (DT 2801 ${ }^{\mathrm{A}}$, Data Transition, Marlboro, MA, USA) at a sampling frequency of $200 \mathrm{~Hz}$ (13). $\mathrm{V}_{\mathrm{t}}$ was obtained by digital integration of the flow signal. The accuracy of the flow signal provided was tested by comparing different volume values from the ventilator (electronically integrated flow signal) with volumes simultaneously measured with a dry spirometer within the $V_{t}$ range. The transducer that provided $\mathrm{P}_{\text {tr }}$ was tested by applying 5 -s PEEP plateaux $(5,10$, 15 and $20 \mathrm{cmH}_{2} \mathrm{O}$ ) during the ventilation of a rubber balloon. The values observed on the electronic display were compared with those measured with a calibrated pressure transducer (270, Hewlett-Packard, Waltham, MA, USA). The flow resistive properties of the equipment (endotracheal tube plus connectors) were experimentally calculated (14) and subtracted from the obtained resistance. A power function fitting this relationship was determined and used to calculate the resistive pressures dissipated along the equipment at any given flow during the tests (13). The equipment resistance was subtracted whenever necessary, so that the results reported here represent intrinsic resistance values. Expiratory flow became nil before the end of expiration and the onset of inspiratory flow was synchronous with the beginning of the positive pressure, showing that autoPEEP was not present in any patient.

The end inflation occlusion method consists of inflating the relaxed respiratory system with a constant square wave flow provided by a ventilator, followed by a rapid airway occlusion at end inspiration, which is maintained until a plateau in tracheal pressure is achieved. In the present study, a rapid airway occlusion was performed during a constant inspiratory flow and was held for $2 \mathrm{~s}$ of inspiratory pause. Initially, there is a fast drop in tracheal pressure $\left(\Delta \mathrm{P}_{1}\right)$ from the peak airway pressure $\left(\mathrm{P}_{0}\right.$ or $\left.\mathrm{P}_{\text {trmax }}\right)$ to a deflection in the pressure curve $\left(\mathrm{P}_{1}\right)$, followed by a slower decay $\left(\Delta \mathrm{P}_{2}\right)$ until an apparent plateau is reached, which represents respiratory system static elastic recoil pressure $\left(\mathrm{P}_{2}\right.$ or $\left.\mathrm{P}_{\mathrm{el}, \mathrm{rs}}\right)$ (Figure 1). $\Delta \mathrm{P}_{1}$ corresponds to the pressure loss across the airways, with some contribution of rapid resistive components of the chest wall, where $\Delta \mathrm{P}_{2}$ represents pressure dissipation due to lung and chest wall viscoelastic properties. $\left(\Delta \mathrm{P}_{1}+\Delta \mathrm{P}_{2}\right)$ divided by the previous inspiratory flow gives the total resistance of the respiratory system $\left(\mathrm{R}_{\mathrm{rsmax}}\right)$. $\Delta \mathrm{P}_{1}$ divided by the preceding flow gives minimal value of resistance $\left(\mathrm{R}_{\text {init }}\right)$, which is due mainly to airway resistive properties. $\Delta \mathrm{P}_{2}$ divided by the inspiratory flow immediately preceding airway occlusion indicates tissue initial resistance $\left(\mathrm{R}_{\text {diff }}\right)$ or $\left(\Delta \mathrm{P}_{2}\right)$. Bates et al. (11) propose two values for respiratory system resistance: one that would be obtained in the absence of unequal time constants within the system and that is not affected by stress relaxation, corresponding to $\mathrm{R}_{\text {init }}\left(\Delta \mathrm{P}_{1}\right)$; the other reflects the mechanical unevenness within the system and stress relaxation $\mathrm{R}_{\text {diff }}\left(\Delta \mathrm{P}_{2}\right)$. The overall $\mathrm{R}_{\mathrm{rsmax}}$ corresponds to addition of $R_{\text {diff }}$ and $R_{\text {init }}(15)$. To avoid auto-PEEP each maneuver was performed at the bedside by allowing a complete expiration to zero end-expiratory pressure (ZEEP) at each step of increasing PEEP, and observing the straight part of the $\mathrm{P}-\mathrm{V}$ curve.

\section{Hemodynamic data acquisition}

Mean arterial pressure (MAP, $\mathrm{mmHg}$ ), mean pulmonary artery pressure (MPAP, $\mathrm{mmHg}$ ), pulmonary capillary wedge pressure (PCWP, $\mathrm{mmHg}$ ) and right atrial pressure (RAP, $\mathrm{mmHg}$ ) were measured. Cardiac output $(\mathrm{CO}, 1 / \mathrm{min})$ was measured in triplicate and each reported value was the mean of the three successive measurements (Model 9520, American Edwards Laboratories, Santa Ana, CA, USA). Immediately after CO was measured, arterial and mixed venous blood samples were collected and arterial and 
venous saturation $\left(\mathrm{SaO}_{2}, \mathrm{SvO}_{2}\right)$ was measured with a Radiometer OSM 3 hemoxymeter and partial oxygen pressures $\left(\mathrm{PaO}_{2}, \mathrm{PvO}_{2}\right.$; $\mathrm{mmHg}$ ) were measured using standard electrodes (Radiometer, Copenhagen, Denmark). Cardiac index $\left(\mathrm{CI}, 1 \mathrm{~min}^{-1} \mathrm{~m}^{-2}\right)$, systemic and pulmonary vascular resistance (SVR, PVR, dyne $\left.\mathrm{s}^{-1} \mathrm{~cm}^{-5}\right)$, right ventricular stroke work index (RVSWI, $\mathrm{g} \mathrm{m}^{-1} \mathrm{~m}^{-2}$ ), left ventricular stroke work index (LVSWI, $\mathrm{g} \mathrm{m}^{-1} \mathrm{~m}^{-2}$ ), intrapulmonary shunt $(\mathrm{Qs} / \mathrm{Qt})$, alveolar arterial oxygen gradient $\left(\mathrm{G}(\mathrm{A}-\mathrm{a}) \mathrm{O}_{2}\right)$, oxygen transport $\left(\mathrm{DO}_{2}, \mathrm{ml} \mathrm{min}^{-1} \mathrm{~m}^{-2}\right)$, oxygen consumption $\left(\mathrm{VO}_{2}, \mathrm{ml} \mathrm{min}^{-1} \mathrm{~m}^{-2}\right)$, and oxygen extraction rate $\left(\mathrm{O}_{2} \mathrm{ER}, \%\right)$ were calculated using standard formulas.

\section{Study design}

After admission to the ICU, the patients had their volemic status adjusted, maintaining an end point of PCWP of $6 \mathrm{mmHg}$ and RAP of $4 \mathrm{mmHg}$ throughout the study. During data acquisition the patients were randomized and remained anesthetized and paralyzed. Additional doses of fentanyl, midazolam and pancuronium bromide were given whenever necessary. Respiratory mechanics and hemodynamics were measured after 15 min of application of three different PEEP levels: 5, 10 and $15 \mathrm{cmH}_{2} \mathrm{O}$ including ZEEP. A pause of 20 min was allowed between each PEEP application period, when the ven-

Table 1 - Respiratory mechanical data.

$\mathrm{E}_{\mathrm{rs}}$, Respiratory system elastance $\left(\mathrm{cmH}_{2} \mathrm{O} / \mathrm{l}\right) ; \mathrm{R}_{\mathrm{rsmax}}$, respiratory system resistance $\left(\mathrm{cmH}_{2} \mathrm{O} \mathrm{I}^{-1} \mathrm{~s}^{-1}\right) ; \Delta \mathrm{P}_{1}$, airway resistance $\left(\mathrm{cmH}_{2} \mathrm{O} \mathrm{I}^{-1} \mathrm{~s}^{-1}\right) ; \Delta \mathrm{P}_{2}$, viscoelastic resistance $\left(\mathrm{cmH}_{2} \mathrm{O} \mathrm{I}^{-1} \mathrm{~s}^{-1}\right)$; ZEEP, zero end-expiratory pressure $\left(0 \mathrm{cmH}_{2} \mathrm{O}\right)$; PEEP, positive endexpiratory pressure $\left(5,10\right.$ and $\left.15 \mathrm{cmH}_{2} \mathrm{O}\right)$. $\mathrm{E}_{\mathrm{rs}}$ : $* \mathrm{P}<0.05$ compared to $5 \mathrm{~cm} \mathrm{H}_{2} \mathrm{O}$ PEEP and ZEEP. $\mathrm{R}_{\mathrm{rsmax}}$ and $\triangle \mathrm{P}_{1}$ : $* \mathrm{P}<0.05$ compared to their respective ZEEP (ANOVA).

\begin{tabular}{|c|c|c|c|c|}
\hline & \multirow{2}{*}{$\frac{\text { ZEEP }}{0}$} & \multicolumn{3}{|c|}{ PEEP } \\
\hline & & 5 & 10 & 15 \\
\hline $\mathrm{E}_{\mathrm{rs}}$ & $23.49 \pm 1.21$ & $21.89 \pm 0.70$ & $18.86 \pm 1.13^{*}$ & $18.41 \pm 0.82 *$ \\
\hline $\mathrm{R}_{\text {rsmax }}$ & $13.12 \pm 0.79$ & $11.94 \pm 0.55^{*}$ & $11.42 \pm 0.71^{*}$ & $10.32 \pm 0.57^{*}$ \\
\hline$\Delta \mathrm{P}_{1}$ & $11.60 \pm 0.75$ & $10.85 \pm 0.58^{*}$ & $10.43 \pm 0.66^{*}$ & $9.42 \pm 0.57^{*}$ \\
\hline$\Delta \mathrm{P}_{2}$ & $3.76 \pm 0.49$ & $3.96 \pm 0.55$ & $4.41 \pm 0.66$ & $4.51 \pm 0.63$ \\
\hline
\end{tabular}

tilatory parameters returned to initial values. In order to avoid interference during the measurement period, neither end expiratory nor sustained inflation was used during or between measurement periods. In each set of measurements, including ZEEP, 7 to 10 breath cycles were pooled and averaged to provide one data point. In order to remove time from the end of surgery as an influencing variable, the sequence of PEEP level application was randomized.

\section{Statistical method}

Data were analyzed statistically by analysis of variance (ANOVA) for repeated measures followed by the Tukey test to determine the differences between the established study points within groups, and by the Student $t$ test to determine differences between groups. The level of significance was set at $\mathrm{P}<0.05$.

\section{Results}

All patients had an uncomplicated clinical course and were discharged from the ICU within $48 \mathrm{~h}$ after admission. No patient required re-operation for bleeding or for any other cause. The results are shown in Tables 1 to 4 .

\section{Respiratory mechanical data}

Along with PEEP application we can observe a progressive decrease of respiratory elastance (Table 1). The elastance $\left(\mathrm{cmH}_{2} \mathrm{O} / \mathrm{l}\right)$ was not significantly modified by PEEP from zero $(23.49 \pm 1.21)$ to $5 \mathrm{cmH}_{2} \mathrm{O}$ $(21.89 \pm 0.70)$. However, a significant decrease $(\mathrm{P}<0.0003)$ at $10 \mathrm{cmH}_{2} \mathrm{O}$ PEEP $(18.86$ $\pm 1.13)$, as well as $(\mathrm{P}<0.0001)$ at $15 \mathrm{cmH}_{2} \mathrm{O}$ $(18.41 \pm 0.82)$ was observed after PEEP application.

A progressive reduction of the total resistance of respiratory system along with PEEP increment was observed. Values of $R_{\text {rsmax }}$ decreased significantly from $13.12 \pm 0.79$ 
$\left(\mathrm{cmH}_{2} \mathrm{O} \mathrm{l}^{-1} \mathrm{~s}^{-1}\right)$ at ZEEP to $11.94 \pm 0.55$ $(\mathrm{P}<0.0197)$ at $5 \mathrm{cmH}_{2} \mathrm{O}, 11.42 \pm 0.71$ $(\mathrm{P}<0.0255)$ at $10 \mathrm{cmH}_{2} \mathrm{O}$ and $10.32 \pm 0.57$ $(\mathrm{P}<0.0002)$ at $15 \mathrm{cmH}_{2} \mathrm{O}$ of PEEP. The same phenomenon was observed in airway resistance. $\Delta \mathrm{P}_{1}$ represents the fast decay phase of airway pressure after inspiratory airway occlusion and is represented by the interval between $\mathrm{P}_{0}$ and $\mathrm{P}_{1}$ (Figure 1). The $\Delta \mathrm{P}_{1}$ values decreased significantly from $11.60 \pm 0.75$ $\left(\mathrm{cmH}_{2} \mathrm{O}\right)$ without any PEEP to $10.85 \pm 0.58$ $(\mathrm{P}<0.0242)$ at $5 \mathrm{cmH}_{2} \mathrm{O}$ of PEEP, $10.43 \pm$ $0.66(\mathrm{P}<0.0491)$ at $10 \mathrm{cmH}_{2} \mathrm{O}$ of $\mathrm{PEEP}$, and $9.42 \pm 0.57(\mathrm{P}<0.0003)$ at $\mathrm{PEEP}$ of $15 \mathrm{cmH}_{2} \mathrm{O}$ (Figure 2).

$\Delta \mathrm{P}_{2}$ represents the slow decay phase of airway pressure after inspiratory airway occlusion and is represented by the interval between $\mathrm{P}_{1}$ and $\mathrm{P}_{2}$ (Figure 1). $\Delta \mathrm{P}_{2}\left(\mathrm{cmH}_{2} \mathrm{O}\right)$ did not change significantly with PEEP. A slight increase of this parameter was observed from $3.76 \pm 0.49$ (ZEEP) to $3.96 \pm 0.55\left(5 \mathrm{cmH}_{2} \mathrm{O}\right.$ of PEEP), $4.41 \pm 0.66\left(10 \mathrm{cmH}_{2} \mathrm{O}\right.$ of PEEP $)$, and $4.51 \pm 0.63\left(15 \mathrm{cmH}_{2} \mathrm{O}\right.$ of PEEP $)$ $(\mathrm{P}<0.4869)$. The variation of total resistance and its subcomponents data along with PEEP are represented in the Figure 2.

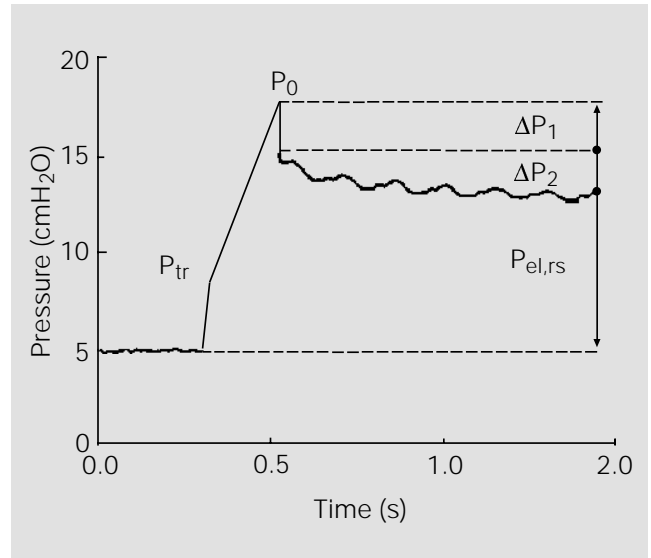

Figure 1 - Flow and pressure curves used for the evaluation of respiratory mechanical properties by the end inspiratory occlusion method. $P_{\text {tr: }}$ Tracheal pressure; $\mathrm{P}_{0}$ or $\mathrm{P}_{\text {trmax }}$ : peak airway pressure; $\mathrm{P}_{2}$ or $\mathrm{P}_{\mathrm{el}, \mathrm{rs}}$ : static elastic recoil pressure; $R_{\text {init }}$ $\left(\Delta \mathrm{P}_{1}\right)$ : minimal value of resistance; $R_{\text {diff }}\left(\Delta P_{2}\right)$ : mechanical unevenness within the system and stress relaxation; $\mathrm{R}_{\mathrm{rsmax}}$ : total respiratory system resistance, corresponding to the sum of $R_{\text {diff }}$ and $R_{\text {init. }}$

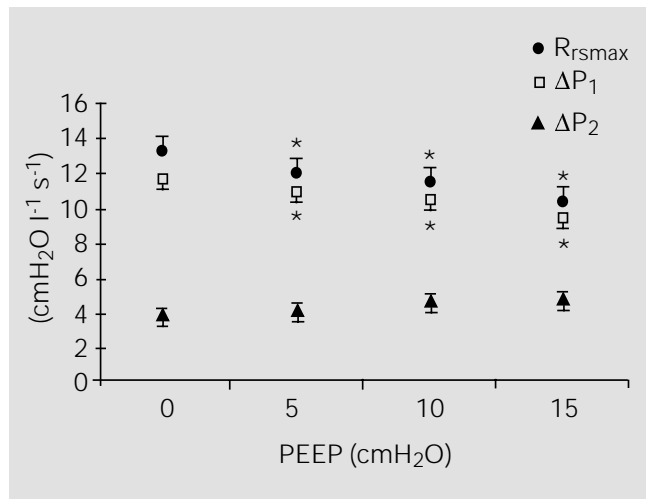

Figure 2 - Total resistance $\left(R_{\text {rsmax }}\right)$ variance and subcomponents $\left(\Delta \mathrm{P}_{1}\right.$ and $\left.\Delta \mathrm{P}_{2}\right)$. Airway resistance-dependent pressure gradient $\left(\Delta \mathrm{P}_{1}\right)$ shows a significant and progressive fall along with positive end-expiratory pressure (PEEP) application from baseline to $5(P<0.0242), 10$ $(\mathrm{P}<0.0491)$ and $15(\mathrm{P}<0.0003)$ $\mathrm{cmH}_{2} \mathrm{O}$. The viscoelastic resistance-dependent pressure gradient $\left(\Delta \mathrm{P}_{2}\right)$ presents a nonsignificant tendency to increase with PEEP increase (ANOVA).

Table 2 - Hemodynamic data.

$\mathrm{Cl}$, Cardiac index $\left(\mathrm{I} \mathrm{min}^{-1} \mathrm{~m}^{-2}\right)$; MAP, mean pulmonary artery pressure; PCWP, mean pulmonary capillary wedge pressure $(\mathrm{mmHg})$; RAP, right atrium pressure $(\mathrm{mmHg})$; MAP, mean arterial pressure $(\mathrm{mmHg})$; LVSWI, left ventricular stroke work index $\left(\mathrm{g} \mathrm{m}^{-1} \mathrm{~m}^{-2}\right)$; RVSWI, right ventricular stroke work index $\left(\mathrm{g} \mathrm{m}^{-1} \mathrm{~m}^{-2}\right)$; PVR, pulmonary vascular resistance (dyne $\mathrm{s}^{-1} \mathrm{~cm}^{-5}$ ); SVR, systemic vascular resistance (dyne $\mathrm{s}^{-1} \mathrm{~cm}^{-5}$ ); ZEEP, zero end-expiratory pressure $\left(0 \mathrm{cmH}_{2} \mathrm{O}\right)$; $\mathrm{PEEP}$, positive end-expiratory pressure $\left(5,10\right.$ and $\left.15 \mathrm{cmH}_{2} \mathrm{O}\right)$. $* \mathrm{P}<0.05$ compared to respective ZEEP (ANOVA).

\begin{tabular}{|c|c|c|c|c|c|}
\hline & \multirow{2}{*}{\multicolumn{2}{|c|}{$\begin{array}{c}\text { ZEEP } \\
0\end{array}$}} & \multicolumn{3}{|c|}{ PEEP } \\
\hline & & & 5 & 10 & 15 \\
\hline $\mathrm{Cl}$ & $3.90 \pm$ & 0.22 & $3.43 \pm 0.17 *$ & $3.31 \pm 0.22 *$ & $3.10 \pm 0.22^{*}$ \\
\hline MPAP & $14.30 \pm$ & 1.09 & $14.40 \pm 1.00$ & $17.30 \pm 1.07 *$ & $19.10 \pm 1.04 *$ \\
\hline PCWP & $8.90 \pm$ & 1.21 & $8.30 \pm 0.80$ & $10.30 \pm 0.64$ & $11.80 \pm 0.79 *$ \\
\hline RAP & $6.30 \pm$ & 0.94 & $5.80 \pm 0.78$ & $7.20 \pm 0.84$ & $9.10 \pm 1.10^{*}$ \\
\hline MAP & $86.20 \pm$ & 4.01 & $87.80 \pm 2.99$ & $86.50 \pm 3.22$ & $88.00 \pm 3.87$ \\
\hline LVSWI & $41.90 \pm$ & 3.65 & $38.96 \pm 3.59$ & $36.93 \pm 3.29$ & $33.92 \pm 3.54$ \\
\hline RVSWI & $4.31 \pm$ & 0.49 & $3.80 \pm 0.44$ & $4.66 \pm 0.34$ & $4.43 \pm 0.55$ \\
\hline PVR & $61.80 \pm$ & 6.02 & $78.90 \pm 6.94^{*}$ & $98.40 \pm 13.81 *$ & $109.30 \pm 11.34 *$ \\
\hline SVR & $983.30 \pm$ & 00.60 & $1070.50 \pm 83.48^{*}$ & $1022.69 \pm 135.56^{*}$ & $1169.50 \pm 81.40 *$ \\
\hline
\end{tabular}




\section{Hemodynamic data}

As demonstrated below, the augmentation of intra-thoracic pressure caused by PEEP application determined a depression of the cardiac function expressed by a decrease of cardiac output and derived indexes (Table 2). The elevation of atrial filling pressures as pulmonary arterial pressure also represents the effects of intra-thoracic distending pressure. Cardiac index $\left(1 \mathrm{~min}^{-1} \mathrm{~m}^{-2}\right)$ showed a significant and progressive decrease from $3.90 \pm 0.22$ at ZEEP to $3.43 \pm$ $0.17(\mathrm{P}<0.0260)$ at $5 \mathrm{cmH}_{2} \mathrm{O}$ of PEEP, 3.31 $\pm 0.22(\mathrm{P}<0.0260)$ at $10 \mathrm{cmH}_{2} \mathrm{O}$ of PEEP, and $3.10 \pm 0.22(\mathrm{P}<0.0113)$ at $15 \mathrm{cmH}_{2} \mathrm{O}$ of PEEP. Mean pulmonary artery pressure $(\mathrm{mmHg})$ remained unchanged from ZEEP
$(14.3 \pm 1.09)$ to $5 \mathrm{cmH}_{2} \mathrm{O}$ of PEEP $(14.4 \pm$ $1.00 ; \mathrm{P}<0.8760)$. However, at PEEP of 10 $\mathrm{cmH}_{2} \mathrm{O}$ and at PEEP of $15 \mathrm{cmH}_{2} \mathrm{O}(17.3 \pm$ $1.07, \mathrm{P}<0.0048$ and $19.1 \pm 1.04, \mathrm{P}<0.0005$, respectively) it increased significantly. There was no significant change in PCWP when comparing values at ZEEP $(8.9 \pm 1.21)$ and at $\mathrm{PEEP}$ of $5 \mathrm{cmH}_{2} \mathrm{O}(8.3 \pm 0.80 ; \mathrm{P}<0.4151)$ and $10 \mathrm{cmH}_{2} \mathrm{O}(10.3 \pm 0.64 ; \mathrm{P}<0.4707)$. However, a significant variation occurred at $15 \mathrm{cmH}_{2} \mathrm{O}$ of PEEP $(11.8 \pm 0.79 ; \mathrm{P}<0.0326)$. The right atrium pressure did not change at ZEEP $(6.3 \pm 0.94)$, and 5 and $10 \mathrm{cmH}_{2} \mathrm{O}$ of $\operatorname{PEEP}(5.8 \pm 0.78, \mathrm{P}<0.5366$ and $7.2 \pm 0.84$, $\mathrm{P}<0.2091$, respectively). On the other hand, at $15 \mathrm{cmH}_{2} \mathrm{O}$ of PEEP, it showed a significant elevation $(9.1 \pm 1.10 ; \mathrm{P}<0.0056)$. No significant changes in mean arterial pressure

Table 3 - Respiratory data.

$\mathrm{PaO}_{2}$, Arterial oxygen tension $(\mathrm{mmHg}) ; \mathrm{PaCO}_{2}$, arterial carbon dioxide tension $(\mathrm{mmHg}) ; \mathrm{Qs} / \mathrm{Qt}$, intrapulmonary shunt (\%); $\mathrm{G}(\mathrm{A}-\mathrm{a}) \mathrm{O}_{2}$, alveolar arterial gradient of oxygen $(\mathrm{mmHg})$; ZEEP, zero end-expiratory pressure (0 $\left.\mathrm{CmH}_{2} \mathrm{O}\right)$; PEEP, positive end-expiratory pressure $\left(5,10\right.$ and $\left.15 \mathrm{cmH}_{2} \mathrm{O}\right) . * \mathrm{P}<0.05$ compared to respective ZEEP (ANOVA).

\begin{tabular}{rrccc}
\multicolumn{3}{c}{ ZEEP } & \multicolumn{3}{c}{ PEEP } \\
\cline { 1 - 3 } \cline { 4 - 5 } 0 & 5 & 10 & 15 \\
\cline { 4 - 5 } $261.90 \pm 22.98$ & & $282.00 \pm 26.28$ & $333.60 \pm 24.47^{*}$ & $369.05 \pm 18.91^{*}$ \\
$31.60 \pm 1.15$ & $28.76 \pm 1.18$ & $27.90 \pm 1.32$ & $28.50 \pm 1.55$ \\
$22.26 \pm 2.28$ & $19.64 \pm 2.06$ & $15.71 \pm 1.40^{*}$ & $11.66 \pm 1.24^{*}$ \\
$125.50 \pm 12.59$ & & $103.80 \pm 10.12$ & $52.80 \pm 14.07^{*}$ & $16.33 \pm 6.28^{*}$
\end{tabular}

Table 4 - Peripheral oxygenation indexes.

$\mathrm{CaO}_{2}$, Arterial oxygen content ( $\left.\mathrm{ml} / \mathrm{dl}\right) ; \mathrm{DO}_{2}$, oxygen delivery $\left(\mathrm{ml} \mathrm{min} \mathrm{m}^{-1} \mathrm{~m}^{-2}\right) ; \mathrm{VO}_{2}$, oxygen consumption ( $\mathrm{ml}$ $\mathrm{min}^{-1} \mathrm{~m}^{-2}$ ); $\mathrm{O}_{2} \mathrm{ER}$, oxygen extraction rate (\%); $\mathrm{SvO}_{2}$, mixed venous saturation (\%); ZEEP, zero end-expiratory pressure $\left(0 \mathrm{cmH}_{2} \mathrm{O}\right)$; PEEP, positive end-expiratory pressure $\left(5,10\right.$ and $\left.15 \mathrm{cmH}_{2} \mathrm{O}\right)$. $* \mathrm{P}<0.05$ compared to respective ZEEP (ANOVA).

\begin{tabular}{lrrrrr}
\hline & \multicolumn{2}{c}{ ZEEP } & & \multicolumn{3}{c}{ PEEP } \\
\cline { 2 - 5 } \cline { 5 - 6 } & \multicolumn{1}{c}{0} & & \multicolumn{1}{c}{5} & \multicolumn{1}{c}{10} & 15 \\
\hline $\mathrm{CaO}_{2}$ & $15.89 \pm 0.80$ & & $15.96 \pm 0.77$ & $16.17 \pm 0.76^{*}$ & $16.38 \pm 0.76^{*}$ \\
$\mathrm{DO}_{2}$ & $481.29 \pm 40.11$ & & $435.74 \pm 35.13$ & $423.02 \pm 36.83$ & $432.16 \pm 38.63$ \\
$\mathrm{VO}_{2}$ & $121.93 \pm 11.94$ & & $125.42 \pm 14.53$ & $124.97 \pm 11.24$ & $138.24 \pm 15.21$ \\
$\mathrm{O}_{2} \mathrm{ER}$ & $0.26 \pm 0.02$ & & $0.29 \pm 0.02$ & $0.30 \pm 0.02$ & $0.33 \pm 0.029$ \\
$\mathrm{SVO}_{2}$ & $76.99 \pm 2.19$ & & $74.04 \pm 2.47$ & $73.71 \pm 3.04$ & $71.82 \pm 3.04$
\end{tabular}


were observed when compared to basal values $(86.2 \pm 4.01$ at ZEEP, $87.8 \pm 2.99$ at 5 $\mathrm{cmH}_{2} \mathrm{O}$ of PEEP, $86.5 \pm 3.22$ at $10 \mathrm{cmH}_{2} \mathrm{O}$ of PEEP and $88 \pm 3.87$ at $15 \mathrm{cmH}_{2} \mathrm{O}$ of PEEP $(\mathrm{P}<0.3104))$. When compared with baseline LVSWI (41.9 \pm 3.65 at ZEEP), it decreased to $38.96 \pm 3.59$ at $5 \mathrm{cmH}_{2} \mathrm{O}, 36.93 \pm 3.29$ at $10 \mathrm{cmH}_{2} \mathrm{O}$ and $33.92 \pm 3.54$ at $15 \mathrm{cmH}_{2} \mathrm{O}$ $(\mathrm{P}<0.4680)$. On the other hand, when compared with baseline parameters $(4.31 \pm 0.49)$, RVSWI showed a nonsignificant variation $(\mathrm{P}<0.1073)$ obtained at the PEEP levels of 5 $\mathrm{cmH}_{2} \mathrm{O}(3.8 \pm 0.44), 10 \mathrm{cmH}_{2} \mathrm{O}(4.66 \pm$ $0.34)$, and $15 \mathrm{cmH}_{2} \mathrm{O}(4.43 \pm 0.55)$. When compared with basal values $(61.8 \pm 6.02)$, PVR presented a significant increase with PEEP levels of $5 \mathrm{cmH}_{2} \mathrm{O}(78.9 \pm 6.94$; $\mathrm{P}<0.0141), 10 \quad \mathrm{cmH}_{2} \mathrm{O}(98.4 \pm 13.81$; $\mathrm{P}<0.0083)$, and $15 \mathrm{cmH}_{2} \mathrm{O}(109.3 \pm 11.34$; $\mathrm{P}<0.0011)$. Finally, a variation in SVR was observed when basal values $(943.3 \pm 100.60)$ were compared to PEEP levels of $5 \mathrm{cmH}_{2} \mathrm{O}$ $(1070.5 \pm 83.48 ; \mathrm{P}<0.0047), 10 \mathrm{cmH}_{2} \mathrm{O}$ $(1022.69 \pm 135.56 ; \mathrm{P}<0.0472)$, and 15 $\mathrm{cmH}_{2} \mathrm{O}(1169.5 \pm 81.40 ; \mathrm{P}<0.0186)$.

\section{Respiratory data}

As can be seen in Table 3, the increase of PEEP improved oxygenation, without any interference with carbon oxide excretion. Compared to the baseline parameters (261.9 \pm 22.98 ) there was a nonsignificant change in $\mathrm{PaO}_{2}$ at PEEP of $5 \mathrm{cmH}_{2} \mathrm{O}(282 \pm 26.28$; $\mathrm{P}<0.4696$ ), whereas a significant increase was observed at PEEP of $10 \mathrm{cmH}_{2} \mathrm{O}(333.6 \pm$ 24.47; $\mathrm{P}<0.0011)$ and $15 \mathrm{cmH}_{2} \mathrm{O}(399.05 \pm$ $18.91 ; \mathrm{P}<0.0001) . \mathrm{PaCO}_{2}$ did not vary significantly from basal value $(31.6 \pm 1.15)$ $(\mathrm{P}<0.1293)$ with PEEP of $5 \mathrm{cmH}_{2} \mathrm{O}(28.76 \pm$ 1.18), $10 \mathrm{cmH}_{2} \mathrm{O}(27.9 \pm 1.32)$ and $15 \mathrm{cmH}_{2} \mathrm{O}$ $(28.5 \pm 1.55)$.

Intrapulmonary shunt and alveolar arterial gradient of oxygen represent indexes of oxygenation. The decreasing of both means improvement of gas exchange in the lungs. $\mathrm{G}(\mathrm{A}-\mathrm{a}) \mathrm{O}_{2}$ decreased significantly from basal values of $125.50 \pm 12.59$ to $103.80 \pm 10.12$ at $5 \mathrm{cmH}_{2} \mathrm{O}$ of PEEP. There were additional and significant decreases in the levels measured at PEEP of $10 \mathrm{cmH}_{2} \mathrm{O}(52.80 \pm 14.07$; $\mathrm{P}<0.0023)$ and $15 \mathrm{cmH}_{2} \mathrm{O}(16.33 \pm 6.28$; $\mathrm{P}<0.0001)$. There was a decrease in $\mathrm{Qs} / \mathrm{Qt}$ from control (22.26 \pm 2.28$)$, which was nonsignificant at $5 \mathrm{cmH}_{2} \mathrm{O}$ of PEEP (19.64 \pm 2.06; $\mathrm{P}<0.2829)$, but strongly significant at $10 \mathrm{cmH}_{2} \mathrm{O}$ of $\mathrm{PEEP}(15.41 \pm 1.40 ; \mathrm{P}<0.0064)$ and $15 \mathrm{cmH}_{2} \mathrm{O}$ of PEEP $(11.66 \pm 1.24$; $\mathrm{P}<0.0007)$.

\section{Peripheral oxygenation indexes}

In comparison with basal values of arterial oxygen content $\left(\mathrm{CaO}_{2}=15.89 \pm 0.80 \mathrm{ml} /\right.$ $\mathrm{dl}$ ), there was no significant change at PEEP levels of $5 \mathrm{cmH}_{2} \mathrm{O}(15.96 \pm 0.776 ; \mathrm{P}<0.4468)$, but a significant change occurred at PEEP of $10 \mathrm{cmH}_{2} \mathrm{O}(16.17 \pm 0.763 ; \mathrm{P}<0.0016)$ and 15 $\mathrm{cmH}_{2} \mathrm{O}(16.38 \pm 0.76 ; \mathrm{P}<0.0001)$ (Table 4). There was no significant variation in $\mathrm{DO}_{2}$ $\left(\mathrm{ml} \mathrm{min}{ }^{-1} \mathrm{~m}^{-2}\right)(\mathrm{P}<0.097)$ at PEEP of $5 \mathrm{cmH}_{2} \mathrm{O}$ (435.74 \pm 35.13$), 10 \mathrm{cmH}_{2} \mathrm{O}(423.02 \pm 36.83)$ and $15 \mathrm{cmH}_{2} \mathrm{O}(432.16 \pm 38.63)$, compared to basal parameters $(481.29 \pm 40.11)$. The basal value of oxygen consumption $(\mathrm{ml}$ $\min ^{-1} \mathrm{~m}^{-2}$ ) was $121.93 \pm 11.94,125.42 \pm$ 14.53 at PEEP of $5 \mathrm{cmH}_{2} \mathrm{O}, 124.97 \pm 11.24$ at $10 \mathrm{cmH}_{2} \mathrm{O}$, and $138.24 \pm 15.21$ at 15 $\mathrm{cmH}_{2} \mathrm{O}$. Oxygen consumption did not vary significantly $(\mathrm{P}<0.0790)$. Compared to baseline parameters $(0.26 \pm 0.020)$, a slight but not significant increase in $\mathrm{O}_{2}$ ER (\%) $(\mathrm{P}<0.379)$ was observed at PEEP of $5(0.29$ $\pm 0.024), 10(0.30 \pm 0.21)$ and $15 \mathrm{cmH}_{2} \mathrm{O}$ $(0.33 \pm 0.029)$. Compared to baseline parameters $(76.99 \pm 2.19)$, no significant difference in $\mathrm{SvO}_{2}(\%)(\mathrm{P}<0.2475)$ was observed at PEEP levels of 5 (74.04 \pm 2.47$), 10$ $(73.71 \pm 2.39)$ or $15 \mathrm{cmH}_{2} \mathrm{O}(71.82 \pm 3.04)$.

\section{Discussion}

The usefulness of PEEP throughout the respiratory cycle for the correction of hy- 
poxemia caused by acute respiratory failure has been clinically demonstrated since 1967 (16). Since then, several studies have been performed in order to establish the ideal PEEP that could restore the oxygenation with minimal impairment of oxygen delivery $(4,5,17)$. In order to minimize pulmonary and circulatory negative influences, many authors recommend adjusting PEEP values according to respiratory mechanical properties $(3,18,19)$.

Recently, several methods have been proposed to assess respiratory mechanical properties in artificially ventilated patients $(18,20)$. Respiratory compliance or elastance and airway resistance can be readily calculated using the flow and pressure transducers incorporated into modern mechanical ventilators, if the raw signals can be connected to an external recording device (21). Among these, the constant flow inflation method has been employed by many authors $(12,13,22,23)$. This technique was developed by Bates et al. (11), who reexamined an early analysis by Rattenborg and Holaday (24) of the behavior of the multicompartmental model of the respiratory system. Utilizing the end inflation occlusion method it is possible to measure the elasticity, resistance and its subcomponents of respiratory system.

In the present study a significant change was observed in pulmonary elastance or compliance at PEEP levels of 10 and $15 \mathrm{cmH}_{2} \mathrm{O}$. The decrease in respiratory elastance with PEEP can be explained by a supplementary alveolar recruitment. Normal airway resistance is of the order of $2.5 \mathrm{cmH}_{2} \mathrm{O} \mathrm{l}^{-1} \mathrm{~s}^{-1}$ and significant increases have been described in patients with chronic air flow limitation (26.4 $\left.\mathrm{cmH}_{2} \mathrm{O} \mathrm{l}^{-1} \mathrm{~s}^{-1}\right)$ (21). The increase in airway resistance observed after cardiac surgery may reflect airway wall edema, presence of fluid or secretions within the airway lumen as well as losses of functional lung volume.

Previously we described variations of the overall $\mathrm{R}_{\mathrm{rsmax}}$ and its airway $\left(\Delta \mathrm{P}_{1}\right)$ and viscoelastic $\left(\Delta \mathrm{P}_{2}\right)$ components in patients immediately before and after cardiac surgery (13). There are few studies comparing $R_{\text {rsmax }}$, $\Delta \mathrm{P}_{1}$ and $\Delta \mathrm{P}_{2}$ at different PEEP levels during the postoperative period after cardiac surgery. The significance of $\mathrm{R}_{\text {init }}\left(\left(\mathrm{P}_{\text {trmax }}-\mathrm{P}_{1}\right) /\right.$ flow) or $\left(\Delta \mathrm{P}_{1}\right)$ has only recently been clarified in human beings, as essentially representing airway resistance (24). As described above, the difference between $\mathrm{P}_{1}$ and $\mathrm{P}_{2}$ (i.e., $\Delta \mathrm{P}_{2}$ ) represents the slow postocclusion decay in tracheal pressure and may reflect stress relaxation due to the viscoelastic properties of the respiratory system and possibly the "Pendelluft" phenomenon that represents distribution of air among the different lung regions (11,25-27). In normal subjects, "Pendelluft" probably has a relatively small role, however, this phenomenon may be more evident if there were an increase in time constant inhomogeneities of alveolar inflation and deflation within the lung. It is important to emphasize that $\mathrm{R}_{\mathrm{rsmax}}$ corresponds to the effective resistance at zero respiratory frequency, while $\Delta \mathrm{P}_{1}$ reflects the resistance at high frequency (11). Therefore, $\Delta \mathrm{P}_{2}$, that reflects tissue viscance, is a measure of the frequency dependence of resistance, a considerably important clinical parameter (28). It is important to emphasize that $\mathrm{R}_{\mathrm{rsmax}}$ is always greater than $R_{\text {init }}\left(\Delta P_{1}\right)$. In chronic or acute lung diseases this difference tends to be higher owing to $\mathrm{R}_{\text {diff }}\left(\Delta \mathrm{P}_{2}\right)$ elevation (20). In the present study we observed a significant decrease in $\mathrm{R}_{\mathrm{rsmax}}$ due to a significant decrease in $\Delta \mathrm{P}_{1}$, with increasing levels of PEEP. This effect can be explained by a probable increase in airway radius due to radial forces applied by the alveolar parenchyma on the airway wall. These data confirm a basic principle of respiratory mechanics, i.e., that flow resistance decreases with increasing lung volume, as determined by changes in $\Delta \mathrm{P}_{1}(29,30)$. The decrease in $\Delta \mathrm{P}_{1}$ and the nonsignificant effect of PEEP on $\Delta \mathrm{P}_{2}$ lead to a decrease in $R_{r s m a x}$. These findings in 
humans are in contrast with those observed in cats, since it was demonstrated in this species that $\mathrm{R}_{\mathrm{rsmax}}$ increases with lung volume (30) because of the increase in parenchyma viscoelastic losses. On the other hand, at fixed tidal volume, $\mathrm{R}_{\mathrm{rsmax}}$ could decrease with increased flow as demonstrated in adult respiratory distress syndrome patients (23).

Although $\Delta \mathrm{P}_{2}$ increased with increasing PEEP, this variation was not considered to be statistically significant. As previously mentioned, $\Delta \mathrm{P}_{2}$ reflects "Pendelluft" phenomena and stress relaxation; however, it is difficult to say which of the two was more prominent in the present study. The term stress relaxation used in this text refers to the phenomena of lung accommodation to positive intra-alveolar pressure, probably caused by the interstitial lung fibrillar matrix realignment and/or by a decrease of the forces generated by superficial tension. A stress relaxation increase is normally related to tissue edema and/or collapsed alveoli, a common situation after cardiac surgery, which is resolved by the alveolar recruitment effect of PEEP. On the other hand, $\Delta \mathrm{P}_{2}$ may increase with PEEP, thus reflecting the volume dependency of stress relaxation. The elevation of tissue viscance observed in our study was not significant, but further studies are necessary to better characterize the effects of PEEP on lung viscance. The current methods frequently employed in ICU to evaluate mechanical properties in artificially ventilated patients (i.e., dynamic and static compliance as well as total airway resistance) are probably not enough to detect changes in tissue viscance. Whether the observed PEEP-associated tendency to tissue viscance elevation in this study represents a mechanical adverse effect that speaks against the use of PEEP is a point that needs more study. Probably the use of other approaches, such as increasing inspiratory flow, may cancel the small increase in tissue viscance observed in the present data (27).
Qs/Qt and $\mathrm{G}(\mathrm{A}-\mathrm{a}) \mathrm{O}_{2}$ decreased concurrently with the changes in respiratory elastance. It is important to point out that PEEP values above $10 \mathrm{cmH}_{2} \mathrm{O}$ are not commonly recommended after cardiac surgery due to a possible decrease in cardiac output. Although the cardiac index fell from 3.31 to $3.101 \mathrm{~min}^{-1} \mathrm{~m}^{-2}$, when we changed the PEEP level from 10 to $15 \mathrm{cmH}_{2} \mathrm{O}$ the oxygenation improvement caused by the decrease in $\mathrm{Qs} / \mathrm{Qt}$ maintained $\mathrm{DO}_{2}$ at adequate levels. Therefore, considering a Qs/Qt reduction from $19.64 \pm 2.06 \%$ at PEEP of 5 $\mathrm{cmH}_{2} \mathrm{O}$ to $15.71 \pm 1.40 \%$ and $11.66 \pm 1.24 \%$ at PEEP of 10 and $15 \mathrm{cmH}_{2} \mathrm{O}$, respectively, values from 10 to $15 \mathrm{cmH}_{2} \mathrm{O}$ may be necessary to reduce the shunt fraction after cardiac surgery.

In this study there was a significant increase in atrial filling pressure as well as in pulmonary vascular resistance, an effect which is probably related to increased intrathoracic and pleural pressure observed with increasing PEEP. As demonstrated by other studies at $10 \mathrm{cmH}_{2} \mathrm{O}$ or higher, $\mathrm{PCWP}$ overestimates left ventricular filling pressure, even if the occluded catheter tip is positioned in the inferior regions of the lung $(31,32)$. One of the critiques of our study is the lack of any correction for increased pleural pressure during PEEP application and making hemodynamic measurements with the patient connected to the ventilator. As expected, we observed a significant variation in right and left pressures mainly at 15 $\mathrm{cmH}_{2} \mathrm{O}$ of PEEP. On the right side of the heart, this fact is probably caused by an obstruction-like effect in venous return (31) on the left; the PCWP elevation is probably due to an artifact transmitted during lung distention which is more evident with increasing PEEP (33). Lozman et al. (34) observed a good correlation between PCWP and left atrium pressure at low levels of PEEP after cardiac surgery; however, at 10 and $15 \mathrm{cmH}_{2} \mathrm{O}$ of PEEP, a discrepancy was observed between PCWP and left atrium 
pressure and no statistical correlation was found between these values. In their study, Pinsky et al. (31) found that in postoperative patients PCWP does not reflect or change with PEEP. However, PCWP reflects transmural pressure (left pressure) only during low levels of PEEP $\left(<5 \mathrm{cmH}_{2} \mathrm{O}\right)$ whereas nadir PEEP obtained by abrupt airway disconnection accurately reflects transmural pressure to at least $15 \mathrm{cmH}_{2} \mathrm{O}$. To minimize a possible interference with respiratory mechanical data acquisition, we did not disconnect our patients from the ventilator to obtain atrial filling pressures. In contrast, Van den Berg et al. (35) employed sustained inspiratory hold maneuver (24 s) in postoperative coronary bypass surgery patients to determine the dynamic changes in right and left ventricular output and found that sustained inspiratory pressure induces proportionally similar decreases in both right and left ventricle output. They concluded that the hemodynamic effects of positive inspiratory pressure ventilation will depend on the degree of lung inflation, on the inspiratory time, and on the time when measurements are made within the ventilatory cycle. In normal volunteers, Huemer et al. (36) employed Doppler hemodynamic indices to show that the fall in cardiac output during PEEP is caused by a reduction in ventricular filling due to decreased venous return. Our data, despite the fall in cardiac index, showed that $\mathrm{DO}_{2}$ and $\mathrm{VO}_{2}$ were preserved; in addition, $\mathrm{CaO}_{2}$ increments due to the PEEPrelated increase in oxygen saturation were also able to partially compensate for the hemodynamic impairment. According to our results, although PEEP therapy above 10 $\mathrm{cmH}_{2} \mathrm{O}$ substantially increases oxygenation, it should be cautiously applied, especially in patients with marginal cardiac function due to contractility disturbances or hypovolemia. The positive results from PEEP higher than $10 \mathrm{cmH}_{2} \mathrm{O}$ related to reduction in airway resistance and compliance restoration due to alveolar recruitment should be care- fully weighed against undesirable hemodynamic effects.

\section{Validity and limitations of measurements of respiratory mechanics in patients}

Among the several techniques available to study respiratory mechanics during mechanical ventilation, the single breath method (SBM) (37), the end-inflation occlusion method (EIOM) (11), and the interrupter technique (IT) (38) have been successfully applied to normal humans or patients with acute respiratory failure (1,21-23,39). SBM allows a detailed account of respiratory system resistive properties throughout relaxed expiration. At a particular constant inspiratory flow, EIOM analyzes the frequencydependent behavior of respiratory system resistance (giving the infinite frequency and zero frequency resistances) and splits it into its homogeneous and uneven components, i.e., that corresponding to the combined summation of series/parallel elements, and that resulting from time constant inequalities within the system and/or stress relaxation, respectively. IT allows the study of volume and flow dependence of the resistive and elastic mechanical properties of the respiratory system by means of brief airway occlusions during relaxed expiration. In the present study, we utilized the EIOM because we are more confident in this procedure. Some conditions may modify the values obtained by EIOM. First, the magnitude of $\Delta \mathrm{P}_{2}$ can be influenced by the compliance and the resistance of the equipment. Unless equilibration of airway and alveolar pressure is complete, airway open pressure does not reflect the elastic recoil pressure of the respiratory system. An overestimation of $\Delta \mathrm{P}_{2}$ because of insufficient expiratory pause results in underestimation of resistive pressure and overestimation elastance. The ideal application of EIOM requires an instantaneous occlusion of the open airway pressure, which is possible to achieve since the occlusion valve 
of the ventilator has a latency in occlusion time. There could be an underestimation of the resistive pressures used to compute $\mathrm{R}_{\mathrm{rsmax}}$ and $\Delta \mathrm{P}_{1}$ because during the closure of the system some flow is still present and will cause an increase in lung volume and consequently in elastic recoil pressure and $\Delta \mathrm{P}_{1}$.

At a constant flow $\mathrm{R}_{\mathrm{rsmax}}$ increases with lung volume, reflecting the volume dependence of stress relaxation. At a constant inflation volume $\mathrm{R}_{\mathrm{rsmax}}$ decreases with increasing flow, exhibiting a minimum value at a flow rate substantially higher than the eupneic flow range. In order to interpret measurements of respiratory system mechanics correctly, the investigator must be aware of the underlying assumptions and the clinical conditions under which they are violated (39). Throughout this study, we assumed that volume, pressure and flow data are derived from appropriately calibrated instruments and that inspired gas has been delivered at a constant flow (square wave flow on the ventilator), situations that, if unrecognized, will lead to erroneous results. Particular emphasis is placed on the need for absence of spontaneous respiratory activity, errors due to time-constant inequalities within the lung, the recognition of dynamic hyperinflation, and errors in determining volumes, flows and pressures due to leaks, gas compression, tubing compliance, ventilator malfunction and intrinsic resistance of tracheal tube and inspiratory circuit. The increased values of airway resistance and elastance in our patients obtained at ZEEP conditions suggest that some degree of injury is caused in the lung during the surgical procedure (40).

In conclusion, even though most of the investigations involving PEEP therapy have been carried out on patients with acute respiratory failure, data on its effects on respiratory mechanics in postoperative cardiac patients without respiratory failure are scarce (41). Along with the increase in PEEP we observed a significant decrease in total and airway resistance and in elastance. The dependence of volume on viscoelastic properties showed a slight but not significant tendency to increase with reduction in airway resistance.

\section{Acknowledgments}

We are indebted to Professor Walter A. Zin for his kind assistance throughout this study.

\section{References}

1. Messent M, Sullivan K, Keogh BF, Morgan CJ \& Evans TW (1992). Adult respiratory distress syndrome following cardiopulmonary bypass: incidence and prediction. Anaesthesia, 47: 267-268.

2. Hammermeister KE, Burchfiel C, J ohnson R \& Grover FL (1990). Identification of patients at greatest risk for developing major complications at cardiac surgery. Circulation, 82: 380-389.

3. Hachenberg $T$, Tenling $A$, Nyström $S$, Tyden H \& Hedenstierna G (1994). Ventilation perfusion inequality in patients undergoing cardiac surgery. Anesthesiology, 80: 509-519.

4. Hall IR, Smith SM \& Rocker G (1997). The systemic inflammatory response to cardiopulmonary bypass: pathophysiological, therapeutic, and pharmacological considerations. Anesthesia and Analgesia, 85: 766-782.

5. Craig DB (1981). Postoperative recovery of pulmonary function. Anesthesia and Analgesia, 60: 46-52.

6. Lindeberg $P$, Gunnarsson L, Tokics $L$, Secher $E$, Lundquist $H$, Brismar B \& Hedenstierna G (1992). Atelectasis and lung function in the postoperative period. Acta Anaesthesiologica Scandinavica, 36: 546-553.

7. Lachmann B (1992). Open up the lung and keep the lung open. Intensive Care Medicine, 118: 319-321.

8. Tusman G, Bohm SH, Vazques de Anda GF, do Campo J L \& Lachmann B (1999). Alveolar recruitment strategy improves arterial oxygenation during general anaesthesia. British J ournal of Anaesthesia, 82: 8-13.

9. Valta $P$, Takala J, Elissa $T \&$ Milic-Emili CMJ (1992). Effects of PEEP on respiratory mechanics after open heart surgery. Chest, 102: 227-233.

10. Gammon RB, Shin MS \& Buchalter SE (1992). Pulmonary barotrauma in mechanical ventilation patterns and risk factors. Chest, 102: 568-572.

11. Bates J HT, Ross A \& Milic-Emili J (1985). Analysis of behavior of the respiratory system with constant inspiratory flow. J ournal of Applied Physiology, 58: 1840-1848.

12. Milic-Emili J (1984). Measurement of pressures in the respiratory physiology. In: Otis AB (Editor), Techniques in Life 
Sciences. Elsevier, Ireland, 1-22.

13. Auler J r J OC, Zin WA, Caldeira PRM, Cardoso VW \& Saldiva PHN (1987). Pre and postoperative inspiratory mechanics in ischemic and valvular heart disease. Chest, 92: 984-990.

14. Wright PE, Marini J J \& Gordon B (1989). In vitro versus in vivo comparison of endotracheal tube airway resistance. American Review of Respiratory Disease, 140: 10-16.

15. Mead J \& Whittenberger J L (1954). Evaluation of airway interruption technique as a method for measuring pulmonary air-flow resistance. J ournal of Applied Physiology, 6: 408-416.

16. Asbaugh DG, Bigelow DB, Petty TL \& Levine BE (1967). Acute respiratory distress in adults. Lancet, 2: 319-323.

17. Dorinsky PM \& Whitcomb ME (1983). The effect of PEEP on cardiac output. Chest, 84: 210-216.

18. Suter PM (1985). Assessment of respiratory mechanics in ARDS. In: Zapol WM \& Falke KJ (Editors), Acute Respiratory Failure: Lung Biology in Health and Disease. Marcel Dekker, New York, 507-519.

19. Gattinoni L, Pesenti A, Avalli L, Rossi F \& Bombino M (1987). Pressure-volume curve of total respiratory system in acute respiratory failure. American Review of Respiratory Disease, 136: 730-736.

20. Rossi A, Gottfried SB, Higgs BD, Zochi L, Grassino A \& Milic-EmiliJ (1985). Respiratory mechanics in mechanically ventilated patient with respiratory failure. J ournal of Applied Physiology, 58: 1849-1858.

21. Broseghini C, Brandolese R, Laggi $R$, Polese G, Manzin E \& Milic-Emili J (1988). Respiratory mechanics during the first day of mechanical ventilation in patients with pulmonary edema and chronic airway obstruction. American Review of Respiratory Disease, 138: 355-361.

22. Ruiz Neto PP \& Auler J r J OC (1992). Respiratory mechanical properties during fentanyl and alfentanyl anesthesia. Canadian J ournal of Anaesthesia, 39: 458-465.

23. Auler J r J OC, Saldiva PHN, Martins AM, Carvalho CRR, Negri EM, Hoelz C \& Zin WA (1990). Flow and volume dependence of respiratory system mechanics during constant flow ventilation in normal subjects and in adult respiratory distress syndrome. Critical Care Medicine, 18: 10801086.

24. Rattenborg CC \& Holaday DA (1966). Constant flow inflation of the lungs. Acta Anaesthesiologica Scandinavica, 23: 211223.

25. Bates J HT, Baconnier P \& Milic-Emile J (1988). A theoretical analysis of interrupter technique for measuring respiratory mechanics. J ournal of Applied Physiology, 64: 2204-2214.

26. Otis $A B, M c K e r r o w ~ C B$, Bartlett RA, Mead J , Mcllroy MB, Selverstone NJ \& Radford EP (1956). Mechanical factors in distribution of pulmonary ventilation. J ournal of Applied Physiology, 8: 427-433.

27. Similowsky $T$, Levy $P$, Corbeil $C$, Albala $M$, Pariente $R$, Derenne JP, Bates J H, J onson B \& Milic-EmiliJ (1989). Viscoelastic behavior of lung and chest wall in dogs determined by flow interruption. J ournal of Applied Physiology, 67: 2219-2229.

28. Grimbly G, Tsakishima T, Graham W, Macklen PT \& Mead J (1968). Frequencydependence of flow resistance in patients with obstructive lung disease. J oumal of Clinical Investigation, 47: 1455-1465.

29. Kochi T, Okubo S, Zin WA \& Milic-Emile J (1988). Flow and volume dependence of pulmonary mechanics in anesthetized cats. J ournal of Applied Physiology, 64: 441-450.

30. Kochi T, Okubo S, Zin WA \& Milic-Emile J (1988). Chest wall and respiratory system mechanics in cats: effects of flow and volume. J ournal of Applied Physiology, 64: 2636-2646.

31. Pinsky $M$, Vincent J $-L \&$ Smet De J M (1991). Estimating left ventricular pressure during positive end-expiratory pressure in humans. American Review of Respiratory Disease, 143: 25-31.

32. Mitaka C, Nagura T, Sakanishi N, Tsunoda Y \& Amaha K (1989). Two dimension echocardiography evaluation of inferior vena cava, right ventricle and left ventricle during positive end-expiratory pressure ventilation with varying levels of positive end- expiratory pressure. Critical Care Medicine, 17: 205-210.

33. Pinsky MR (1990). The effect of mechanical ventilation on the cardiovascular system. Critical Care Medicine, 6: 663-678.

34. Lozman J, Powers SR, Older T, Dutton RE, Roy RJ , English M, Marco D \& Eckert $C$ (1974). Correlation of pulmonary wedge and left atrial pressure: a study in the patient receiving positive end-expiratory pressure ventilation. Archives of Surgery, 109: 270-277.

35. Van den Berg PC, Grimbergen CA, Spaan J A \& Pinsky MR (1997). Positive pressure inspiration differentially affects right and left ventricular outputs in postoperative cardiac surgery patients. J ournal of Critical Care, 12: 56-65.

36. Huemer G, Kolev N, Kurs A \& Zimpfer M (1994). Influence of positive end expiratory pressure on right and left atrial ventricular performance assessed by two-dimensional echocardiography. Chest, 106: 67-73.

37. Zin WA, Pengelly LD \& Milic-Emili J (1982). Single-breath method for measurement of respiratory mechanics in anesthetized animals. J ournal of Applied Physiology, 52: 1266-1271.

38. Gottfried SB, Rossi A, Calverley PMA, Zocchi L \& Milic-Emili J (1984). Interrupter technique for measurement of respiratory mechanics in anesthetized cats. J ournal of Applied Physiology, 56: 681-690.

39. Behrakis PK, Higgs BD, Baydur A, Zin WA \& Millic-Emili J (1983). Respiratory mechanics during halothane anesthesia and anesthesia-paralysis in humans. J ournal of Applied Physiology, 55: 1085-1092.

40. Marini JJ (1994). Airway resistance: an old friend revisited. Intensive Care Medicine, 20: 401-402.

41. Dechman GS, Chartrand DA, Ruiz-Neto PP \& Bates JHT (1995). The effect of changing end-expiratory pressure on respiratory system mechanics in open and closed chest anesthetized, paralyzed patients. Anesthesia and Analgesia, 81: 279286. 